\title{
THE DISTRIBUTION AND STRUCTURE OF BRAZILIAN FORESTS
}

\author{
By Pierre Dansereau
}

\author{
University of Montreal, Montreal, 2uebec
}

$\mathrm{T}$

HE EXISTING forest surveys of Brazil are not yet accurate enough to offer definite figures as to the percentage of territory forested. BEVAN (1945) mentions 1,562,000 square miles, whereas AzEvedo (1945) refers to approximately 3,500,000 square miles. The actual area of Brazil itself is variously estimated at 3,275,560 square miles (Bevan, 1945), and 5,288,597 square miles. (Brazilian Department of External Affairs, 1945). The official figure published recently by the Brazilian National Geographic Council (FELIPPE, 1947) is $5,280,466$ square miles.

BEVAN (1945) estimates that 48 per cent of Brazilian territory is forested, whereas AzEVEDo (1945) states that 58 per cent is forested. These figures are dependent upon one's definition of forest in the first place, as opposed to savannah, parkland and brush. At all events, it is well to note that in spite of an unquestionably immense acreage of forests, lumbering is a far from important industry in Brazil (AzEvedo, 1945). In fact, it ranks as the 16th in the world (PotsCH, 1945) among timber exporting countries, and comes after such small countries as Austria and Latvia.

Brazil extends from about $5^{\circ}$ lat. $\mathrm{N}$ to approximately $34^{\circ}$ lat. $\mathrm{S}$. It appears on the map in triangular outline as a broad precambrian shield depressed by the vast Amazon Valley, where recent sediments dominate. It is irregularly overlain by primary deposits in the centre, whereas recent sediments are again present on the eastern margin of the continent (OLIVEIRA and LEONARDOS, 1943).

The highlands of Guiana rise rather more abruptly than those that merge into the Central Plateau from the Amazon. Towards the western frontier, and also in the north-east, are several mountain ranges, running more or less $\mathrm{N}-\mathrm{S}$, some of them of very limited extension. More important are the coastal ranges, parallel to the Atlantic. Much of the Amazon Valley, the Atlantic shoreline lowlands (rarely extending inland more than 50 miles), the Great Pantanal near the Bolivian frontier, and the southernmost part of Rio Grande do Sul do not rise above 200 metres. Most of the remaining surface lies between 200 and 1,000 metres: the Great Central Plateau to the west of the coastal ranges decreases in altitude towards the NW. In the states of Santa-Catarina, Paraná and Minas Gerais, several fairly extensive areas rise above 1000 metres. The highest summits in the coastal ranges are about 3000 metres. (Pico da Bandeira, Agulhas Negras), as is also Mt. Roraima, at the Guiana border.

Fig. 1, redrawn from the Conselho Nacional de Geografai's 1945 map, shows the distribution of climates, according to the KöPPEN (1923) system. Tropical (or A) climates cover most of the country. The Amazonian region (Af) is warm and moist with evenly distributed precipitations, whereas the southeastern Atlantic region has a monsoon regime (Am). The Centre and 

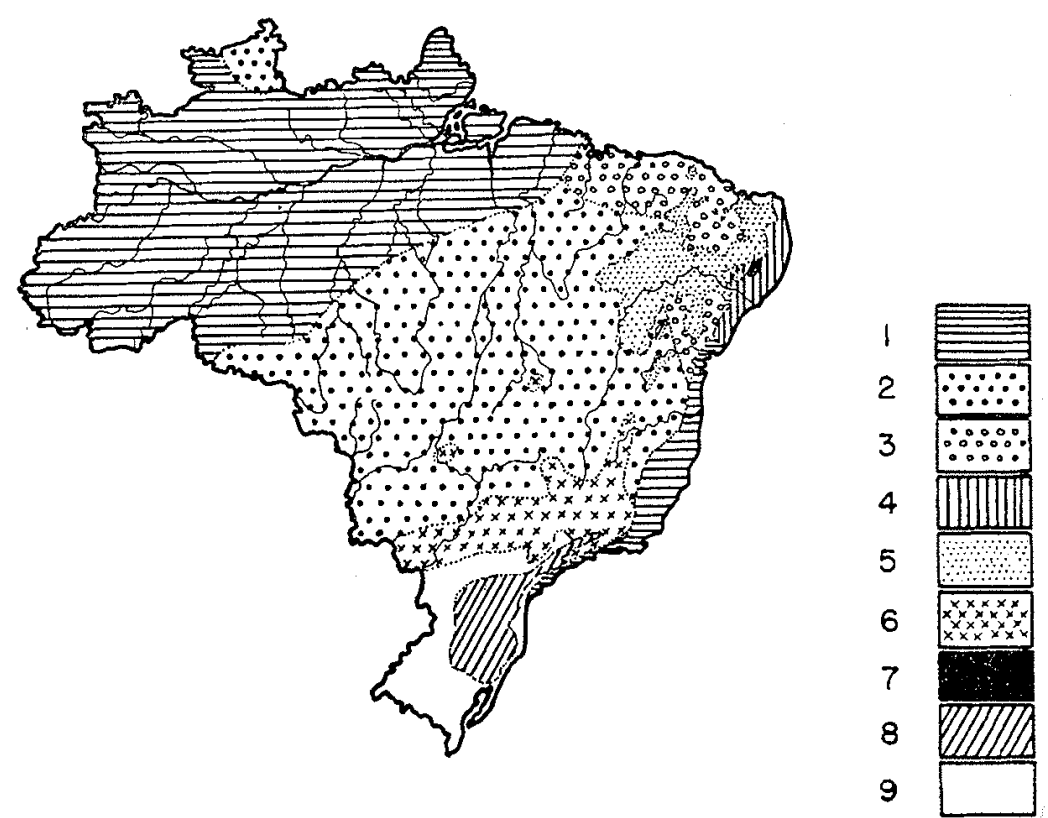

Figure 1. Climates of Brazil, according to the Conselho Nacional de Geografia's 1945 map. 1. Af, Am-Warm, with evenly dietributed rainfall. 2. Aw-Warm, with summer rainfall. 3. Aw'-Warm, with summer-autumn rainfall. 4. As'-Warm, with a rainfall. 5.-BSh-Semi-arid, warm. 6. Gw-Temperate, with gummer . $\mathrm{Cs}^{3}$-Temperate, with autumn-winter rainfall. 8. Cfa-Temperate, with evenly distributed rainfall and warm
tributed rainfall and cool summers.

Northeast have decidedly irregular rains and therefore a dry period occurring in summer $(A w)$, in summer and autumn $(A w)$, or in autumn and winter (As'). The truly dry (or B) climates have a limited extension in the Northeast and are of the semi-arid (BSh) type.

The lower third of Brazil, although it reaches north of the Tropic of Capricorn, is in the temperate (or C) zone: a more or less irregular E-W belt inland from the Coastal Range is temperate with summer rains $(\mathrm{Cw})$; all of the territory to the south of that has evenly distributed rainfall and mostly cool summers $(\mathrm{Cfb})$, whereas a broad enclave differs by its warm summers (Cfa).

\section{VegETATION ZONES}

Fig. 2 is a map of the principal vegetation areas. It conforms to the one published by LYMAN B. SMTTH (1945) and is largely drawn from A. J. de SAMPaIo (1945). It is to be noted, however, that Sampaio's map contained some rather obvious exaggerations (especially as to the extension of the so-called "maritime" zone and the caatinga), corrected by SMITH. In fact, the original outline must be credited to Martius (1840). No botanist since his time has achieved as comprehensive a knowledge of the Brazilian flora and vegetation, and subsequent modifications of the frontiers indicated by him have contributed relatively little. 

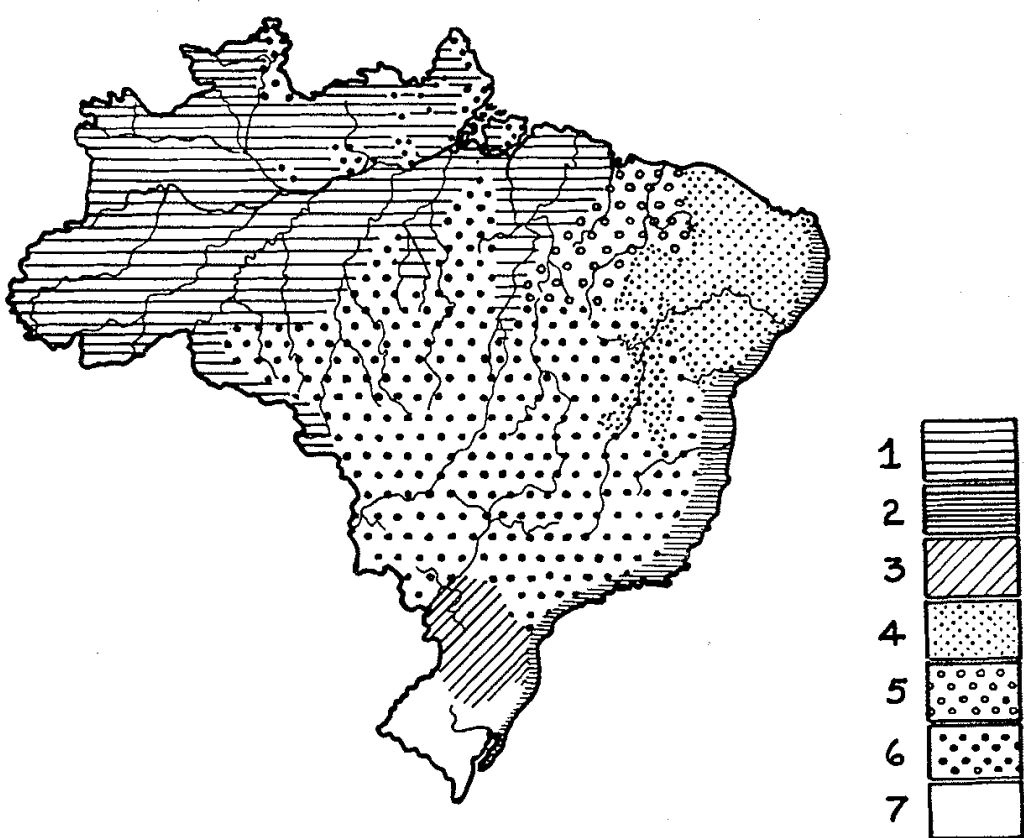
Figure 2. Vegetation zones of Brazil, redrawn from L. B. Smith (1945) and based on
Martius, Sampaio, etc. 1. Amazonian rainforest. 2. Coastal rainforest. 8. Parana pine forest. 4. Catinga. 5. Cocäes. 6. Campos cerrados. 7. Pampa.

The principal vegetation zones of Brazil (Fig. 2) are the following: 1) Amazonian rainforest; 2) Coastal rainforest; 3) Paraná pine forest; 4) Caatinga; 5) Cocāes; 6) Campos cerrados; 7) Pampa. They are characterized much more by formation or structure than by definite and uniform botanical composition. In each one, further study will undoubtedly reveal several climaxareas ("associations", in the Clementsian sense, i.e. units equivalent to the Oak.Hickory, the Beech-Maple, the Oak.Chestnut areas of Eastern North America.)

The dominant types of vegetation in each division have been defined in broad terms. However, uniform criteria are even more sadly lacking in the description of tropical vegetation than they are for temperate countries. Should an area be typified by its climax or by some prevalent subclimax of greater or lesser areal importance? For instance, SHANTZ and ZoN's (1924) map of the vegetation of the United States is quite heterogenous in this respect, inasmuch as subclimaxes (such as white or jack pine forests) are mapped on a basis of equality with oak-hickory or beech-maple. Many vegetation maps of Brazil show the same distortion: SAMparo (1945) outlines a "maritime zone", which consists of early seral stages of the xerosere and halosere. To be sure, such formations are exclusive to the coastal area, but their use as a major criterion is at considerable variance with those 
employed for the delimitation of the other, presumably equivalent, categories. Probably for that reason, SMITH (1945) has not seen fit to recognize it as distinct from the coastal rainforest zone.

A brief description of each major unit is given hereafter, considering the structure and the better known botanical characteristics of the probable climax, together with some outstanding plant associations of other ranks, and the physiographic situations in which they occur. Reference will be made to BEARD's (1944) excellent classification of "climax vegetation in Tropical America", except where such reference necessitates a discussion of the types proposed by him, which discussion exceeds the scope of this paper.

\section{Amazonian rainforest}

The vast, undulating Amazonian sedimentary plain offers several variations of three principal topographic situations: the upland or bench, the varzea or floodplain, and the igapó or permanently moist lowland. Upland, or mesic terrain above the flood level, is covered with typical "rainforest" (BEARD, 1944). It is dominated by trees having high requirements such as Bertholletia excelsa (Brazil-nut trees or castanheira do Pará), Dinisia excel$s a$, and others. These trees grow to a height sometimes exceeding 150 feet. Lianas belonging to several genera of the Leguminosae and to the genus Strychnos are very common. The herbaceous vegetation is not very abundant. The varzea, presenting an immature topography and congested drainage, is very favourable to the rubber trees (Hevea brasiliensis, $H$. benthamiana) and to a dense undergrowth of palms and broadleaved coarse herbaceous plants; epiphytes are also quite numerous. Densest of all is the vegetation of the igapó with its wide-ranging variety of trees such a Calophyllum brasiliense, Macrolobium acaciaefolium, Nectandra amazonum, Piranhea trifoliolata, Triplaris surinamensis, Bombax aquaticum, etc.

\section{Coastal rainforest}

This zone extends through some 15 degrees of latitude, covers the usually narrow coastal plain, the more or less stiff escarpment, much of the mountain ous area, and the eastern edge of the great central plateau. Climax forest (BEARD's (1944) "evergreen seasonal" forest) contains many Lauraceae, Apocynaceae, Vochysiacede, tree ferns, many epiphytes (the ferns are especially well represented), few lianas, many species of Begonia and Psy. chotria. Secondary forests are of a striking homogeneity, consisting sometimes exclusively of one or two of the following species: Tibouchina estrellensis, Cassia multijuga var. grandiflora, Alchormea triplinervia, Miconia organensis (Veloso, 1945, Dansereau, 1948). The high altitudes have "montane rainforest", "elfin woodland" (BEARD, 1944) and peat-bogs. The shoreline harbours an extensive development of restinga (or sand bar) vegeta. tion, with strongly xeric species (Mimusops subsericea, Conocarpus erecta, Diplothemium maritimum, Byrsonima sericea) and of mangrove, with three typical tree species: Rhizophora mangle, Avicennia tomentosa and Laguncularia racemosa (DANSEREAU 1947). 


\section{Paraná pine forest}

The coniferous forest lies in the states of Paraná and Santa-Catarina, which they do not entirely cover, and overflows somewhat north and south into Sāo Paulo and Rio Grande do Sul. They do not quite reach the littoral as they are confined to altitudes generally above 600 metres (in the south) and up to 1000 metres. Islands of the Arawserietum angustifoliae also occur in the mountains of the states Sāo Paulo, Rio de Janeiro and Minas Gerais -well above 1000 metres and more nearly at 1500 metres. This formation probably differs greatly from BEARD's (1944) Antillean "mountain pine forest".

A decrease in altitude towards the west brings this forest in contact with the rainforest which dominates on the edge of the Paraná River. There is also an ecotone of parkland towards the south, with decreasing rainfall and contact with the grassland.

\section{Caatinga}

This scrub forest extends in a broad strip across the NE of Brazil and covers almost the entire states of Cearà and Rio Grande do Norte, the hinterland of Parahyba, Pernambuco, Alagoas, and parts of Piauí and Bahia. It is a very heterogeneous formation, with many local variations. BEARD's (1944) "cactus scrub" and "thorn woodland" occur here. LutzelbuRg (1922. 23) has described quite a few types, but in such a way that it is difficult to gain any idea as to climax associations. Edaphic relationships, however, are made a little clearer, in their relationships to the floods that alternate with extreme drying up of the soil. Most of the small trees of that zone have a leafless phase during the dry period. Exceptions are Zizyphus jodzeiro (joazeiro) and Licania rigida (oiticica). Many species of palms are present, the most remarkable being the carnaúba (Copermicia cerifera), restricted to the flood-plain. The entire landscape shows extremely sharp seasonal variations. The damage to primeval vegetation is especially grave and seems, in many cases, irredeemable.

\section{Cocāes}

This is not a very extensive nor very well-defined area. It occupies much of Piauí and Maranhāo and a small part of Goiaz. The babaçú palm (Orbignya martiana) is its principal characteristic; Copernicia cerifera (car. naúba) and Mauritia vinifera (burití) also occur. Much of the vegetation is closely similar to that of the neighbouring cerrado or caatinga. Moisture, however, is available during longer periods than in the preceding zone.

\section{Campos cerrados}

This name is misleading and has caused some confusion in the mapping of Brazilian vegetation. Its meaning in various parts of the country is quite different. At all events a mere glance at the extension of cerrado (Fig. 2), carries the conviction that a broad complex is involved. The Brazilian savan, nah occupies a central position and, as such, comes in direct contact with 
almost all other types. In the centre of Goiaz, the W of Minas Gerais and the $\mathrm{E}$ of Mato Grosso, it is almost certainly climax (Bearo's (1944) "savanna"). On many marginal areas, it probably owes its advance to fires and deforestation. Its outliers in Sao Paulo, described by RAwTTSCHER and his students $(1943,1946)$ seem to be fire disclimaxes or at most preclimax relics.

The cerrado consists of a more or less continuous grassland with scattered trees. The trees are small, of a rather open form, and belong to two principal types: the coriaceous broadleaved evergreen, such as Kielmeyera coriacea, Anona crassiflora, Palicourea rigida, and the finely dissected partly deciduousleaved, such as Stryphnodendron barbitimao, Machaerium acutifolium, Di. morphandra mollis. The grasses are luxuriant during the rainy season, and dry up almost completely in winter: Tristachya chrysothrix, Aristida longifolia, Echinolaena inflexa, etc. A third and most curious category are small plants (chamaephytes) of restricted aerial growth (height: $20.30 \mathrm{~cm}$ ), with an almost incredible root development, 15.20 metres down to the water table (RAWTTSCHER, FERr e RACHD, 1943): Jacaranda decurrens, Anacardium humile, Andira humilis, etc.

\section{Pampa}

It is exceedingly difficult to form any opinion as to the structure and composition of the vegetation of the lower half of Rio Grande do Sul. Most authors do not go beyond a physionomic description of the landscape rather than the vegetation: a rolling grassland country with floodplain forests. Much discussion has taken place as to the status and relative advances of forest and prairie. Pauwels (1941) seems to be the first to have considered the possibility of proclimax status for forest.

As to the composition of the southern Brazilian prairie, only genera are mentioned, among them Poa, Stipa, Eragrostis, Bromus, Briza, Andropogon, etc. Many maps indicate this area as having vegetation similar to that of the cerrado, although the authors recognize the presence of many platinian and andean species. More important still is the absence of trees in the grassland, clearly indicated by LINDMAN (1900). Descriptions of the presumably similar adjacent argentinian pampa (FrenguelLI, 1940, PAROdI, 1945) give no further clue.

\section{The Structure of Brazilian Forests}

The distinction between structure and composition is not usual amongst foresters of temperate and cold regions, nor does it appear as necessary to the recognition of well-defined units. The Society of American Foresters' (1940) types are based on composition and they are called: "Beech-sugar maple" (no. 57), "Silver maple-American elm" (no. 60), "Paper birch-red sprucebalsam fir" (no. 20), "White pine-hemlock" (no. 10), "Gray birch-red maple". (no. 7), etc. No difference is at first hand evident between climax and subclimax communities (although this is mentioned in the description), nor is any segregation (other than areal) implied in the "type groups" ("Northern 

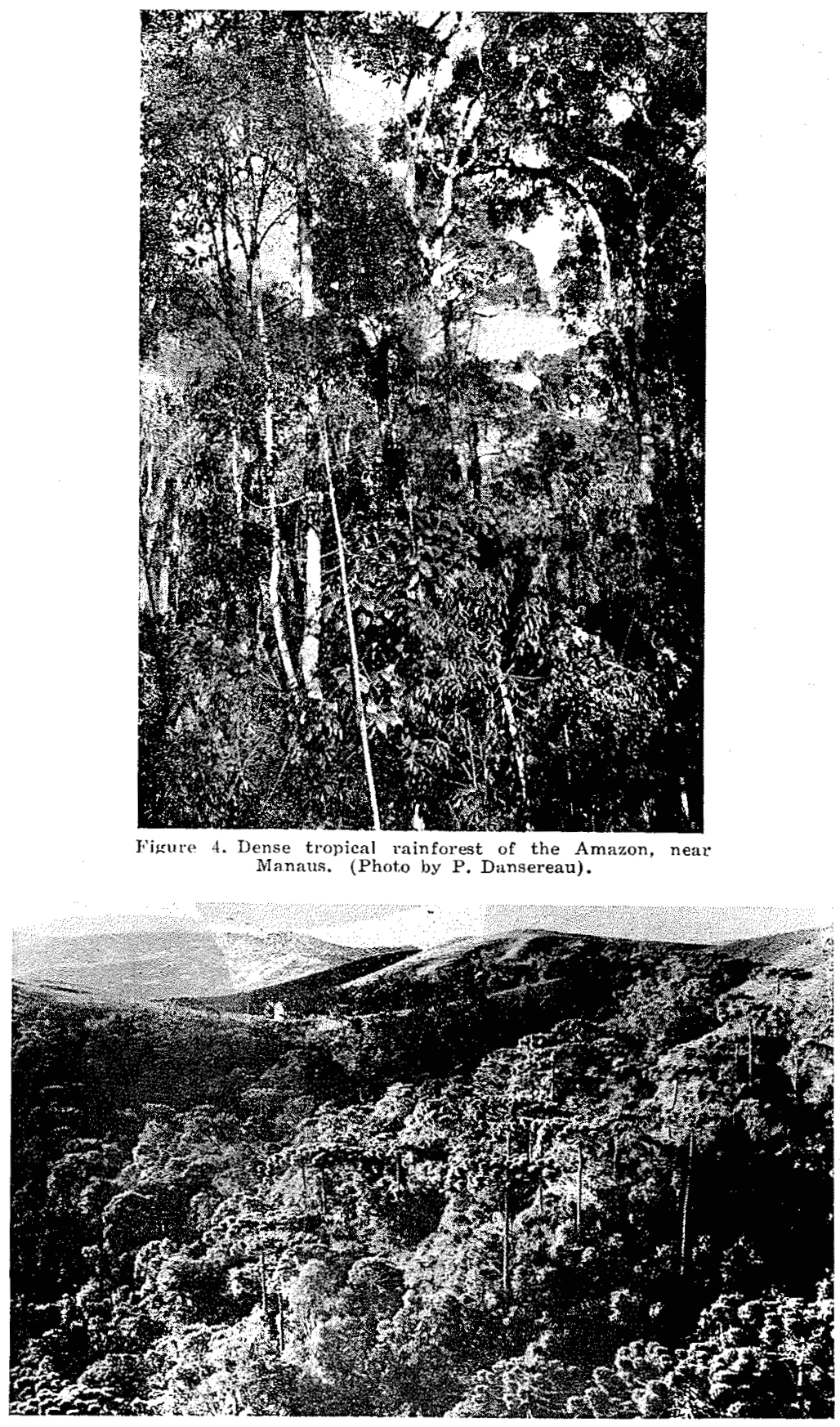

Figure 5, A montane rainforest at about $1800 \mathrm{~m} .$, on the Itatiaia, with Cabralea and Croton, many shrnbs and epiphytes. (Photo by P. Dansereau). 


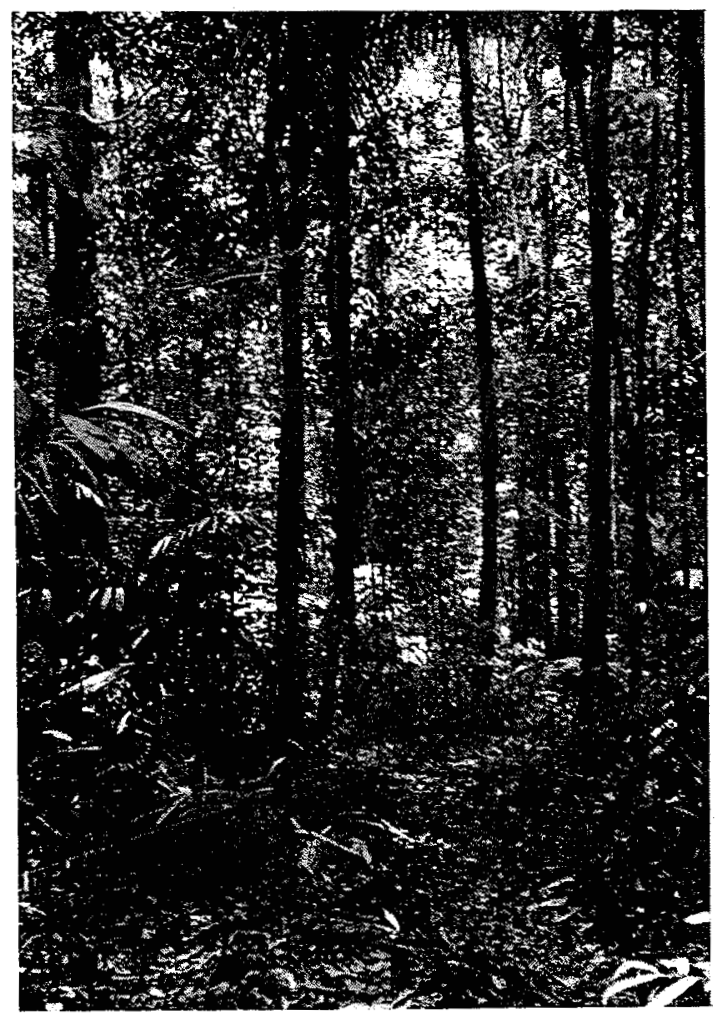

Figure 3. A relic Parana pine forest at Compos do Joldao (State of Sao Paulo), altitude about 1500 metres. The smaller trees are mostly Podocarpus lamberti.

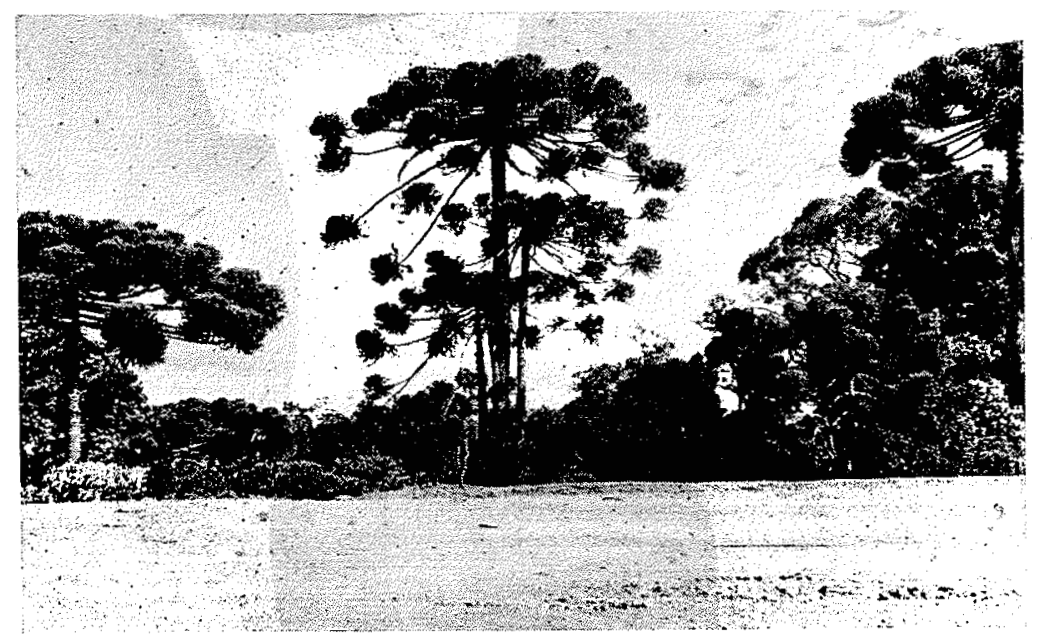

Figure 6. An jsolated Parana pine (Araucaria angustifolia), showing typical branching habit. (Photo by P. Dansereau) 
hardwoods", "White pine", "Spruce-fir", "Post oak", etc.). In fact, the characterization of a forest type by its dominant tree species (v.g. sugar maple, red spruce) is explicit enough, and calls forth a picture of at least the upper synusia with its fundamental biological characteristics (v.g. sugar maple $=$ broad-leaved deciduous tree; red spruce $=$ needle-leaf evergreen) .

This implication is actually of greater biological significance than the mere botanical identity of the species involved. Ecologically, Acer saccharophorum, Betula lutea and 2 uercus borealis are more nearly similar to one another than either of them is to phylogenetically related species, such as Acer saacharinum, Betula populifolia and 2uercus velutina.

However, in cases where dominance does not exist, or is assumed by several species, or varies considerably under approximately identical conditions in a restricted area, a definition of vegetation types by structure is not only more practical, but based on more fundamental criteria. It is well-known that vegetation in the tropics is less homogeneous than in temperate climates (SCHIMPER, 1898, WARMING, 1899, 1909). Equatorial rainforest is supposed to present the acme of heterogeneousness and to escape all definition but the physiognomic.

This may have been somewhat exaggerated. It applies mostly to climax formations and possibly to some subclimaxes in the late hydrosere in the humid tropics. Dominance is quite as visible in the early stages of succession and in many subclimaxes in the tropics as it is in colder areas. Indeed, some climax communities are not too discouragingly deprived of it either, and differ from temperate forests most strikingly in the long list of accidental, and therefore ecologically non-significant species. Also, periodicity is very far from absent in the tropics (WARMING, 1899), even though it does not respond as clearly to meteorological fluctuations as it does in colder climates. VELOSO (1945) has shown that forest species in Teresópolis (Brazil) have rather a short period of flowering and fruiting.

SCHIMPER (1898), WARMING (1909), and many authors since their time, have used a physiognomic-structural system of classifying the proteiform tropical vegetation. Recently BURTT-DAVY (1938) and BRARD (1944) have attempted a revision of these systems and have provided us with excellent categories. I can hardly attempt here to fit the entire Brazilian woody vegetation into this scheme, as the sparseness and incompleteness of the data will allow only the broadest classification. Also, some new types or subtypes would have to be set up, and the present sketch would hardly justify such a procedure. Instead, I propose to describe a few typical stands from the true forest zones of Brazil (1,2,3 of Fig. 2). This I shall do by interpreting some of the available literature and supplementing from my own observations and field notes. I have made many phytosociological surveys in different kinds of forest and can offer a few preliminary notes on their structure and ecological status.

1. The Amazon

Much of the Amazon basin, at least that part indicated as 1 in Fig. 2, is unquestionably forest country. Forest growth being determined by total rainfall, nowhere within that area should there appear climax formations other 
than arborescent. However, fairly large tracts of campo do exist in the Amazon, and fairly close to the river itself.

HUBER (1900), who has probably given the best account of the vegetation of the Lower Amazon, considers them of recent alluvial origin, and therefore seral (although he obviously does not use such a word). He draws arguments from their geomorphological contours, their level, and their flora to show that they are immature communities on immature topography. An interesting feature is the character of the islands of forest scattered in these campos: they do not resemble those of nearby islands in the river, and would seem to conform to a now extinct pattern. That would make the campos subclimax and the forest islands preclimax!

WARMING (1899) has been very insistent in respect to the relative youth of the campos cerrados and their comparative poverty in species: the territiary cerrados of Central Brazil having fewer species than the neighbouring forest and the quaternary cerrados of Northern Brazil and Venezuela having still less.

The forest itself, however, is essentially found in three situations, as de. fined above. The more mesic areas, or uplands, are occupied by rainforest of the equatorial type. The trees are tall (although not always so), have long straight stems (without branches on the lower two-thirds, more or less); the base of the trunk, in many species, is broadened into plank buttresses (sapopemas) extending at right angles to it. Some characteristic species are: Bertholletia excelsa, Saccoglottis uchi, Castilloa ulei, species of Lecythis, Couratari, Tachigalia, etc. Many lianas are present and also climbers, es. pecially Araceae (Anthurium, Monstera, Philodendron). Epiphytes are numerous, including woody species (Ficus, Clusia). Smaller trees are also present, belonging to the genera mentioned above and also to Jacaranda, Ouratea, Picramnia, Siparuna, Sapium and others. Herbaceous vegetation comprises Ravenala guianensis (the American vicariant of the traveller's tree, R. madagascariensis), several Araceae (Dieffenbachia, Caladium, Xanthos, oma), species of Peperomia, Heliconia, Renealmia, Costus, etc. (Huber, 1906). Palms are not very common and are more likely to be found at the forest edge or in clearings (Mauritia, Euterpe, Oenocarpus) as are also rather heliophilous trees such as species of Cecropia, Solanum, Apeiba, Ceiba, Virola, Cordia, and among the herbs, several Desmodium, Pavonia and Cyperaceae.

$A$ virgin forest (Floresta de Flores) which I visited near Manaus had an upper tree-layer of about 100 feet and a coverage of about 75 per cent. (fig. 3). The tallest trees were Dinisia excelsa, and other Leguminosae, species of Ficus (with broad plank buttresses), Lecythis and Lauraceae. Most remarkable was the uneven height of the trees, the Dinisia and a Ficus being "outstanding" (BEARD, 1944). A second synusia of small trees was almost as dense, and included two palms (Euterpe oleracea, Astrocaryum tucuma) and several Sterculiaceae. Lianas were extremely abundant, their twisting, flattered stems hanging from the uppermost branches of the trees: many species of Strychnos were present (they bloom very little, a fungus destroys flowers and fruit), several Loganiaceae, Menispermaceae, Bauhinia. Epiphytes were not very much in evidence and ground vegetation extremely scattered (not unlike the summer aspect of dense climax Beech-Maple forest). Reproduction of the 
tall tree species was good. Animal life was quite inconspicuous: a few birds (among them one of the large araras) and the trails of the paca (Coelogenis paca).

In the varzeas and the igapós, the tree layer is somewhat thinner, the trunks shorter and lower-branched and the undergrowth more luxuriant. The dominance of palms is not unusual. They are very often disposed in concentric belts marking duration of the flood-period, and therefore have excellent indicator value. The three most frequent palms, according to HUBER (1906) are in order of decreasing flood-tolerance: Astrocaryum jauary, A. murumuru and Attalea excelsa. In the straits (paranás) between Marajo island and the mainland, a frequent zonation consists of aquatic prairies of canarana (Panicum spectabile), a formation of aninga (Montrichardia arborescens), followed by Mimosa bushes and three distinct belts dominated by three palms: Manicaria saccifera, Euterpe oleracea, Mauritia flexuosa.

Also typical inhabitants of varzeas are the rubber trees, Hevea brasiliensis on clay soils and $H$. benthamiana on sandy soils (DUCKe in conversation) and the cocoa-tree (Theobroma cacao). Just how do these trees grow in the wild? How many of them can one expect to find per square mile? Will protection, thinning, shading, increase their natural reproduction? Although it seems well established that they fit into a serclimax and not into the climatic climax, very little else seems to be known of their ecological requirements under natural conditions.

There is absence of dominance in the tropical rainforest, according to WARMING (1899), because "these tropical forest trees . . . must stand in quite the same relation to one another as the single individuals of the very same species". In other words, it would seem that there is almost complete overlapping of the requirements and tolerances of a large number of species, which enables them all to take equal advantage of environmental resources. This overlapping is conspicuously absent in the boreal forest, and the ranges of requirements and tolerances are such as to establish an almost perfect coincidence between certain soil and moisture conditions and a very definite flora, sometimes almost irrespective of seed-dispersal. This latter factor, then, in the tropics, may be of greater importance and it may account for local dominance in the Amazon of Bertholletia excelsa or some other species. Of course, earlier phases of forest succession show very clear dominance of, for instance, Cecropia, Ceiba, Mauritia, etc.

\section{The coastal area}

The structure of rainforest in this zone differs mainly from the preceding in the absence or rarity of buttressed trunks. Otherwise, the trees are as greatly developed. Lianas, however, are less frequent and less numerous. Woody epiphytes are not common, whereas herbaceous ones are in very great abundance: Ferns (Polypodiaceae, Hymenophyllaceae), Piperaceae, Bromeliaceae, Orchidaeae and Cactacede. The relief and soils are also very different to those of the Amazon, and favour different species. Lecythis, Aspidosperma, Vochysia, Ouratea, Cabralea, Cariniana, Cedrela, Nectandra are climax 
trees. Tree ferns (Cyathea, Alsophila) and small trees (Drimys winteri, Psychotria spp.) form a tall shrub layer. Climbers, especially Araceae and Begonia, are common. Tall herbs of the araceous, musaceous and marantaceous types are abundant though not conspicuously gregarious except in moist pockets.

The structure and much of the composition of these forests does not vary considerably from sea-level to almost 1500 metres. Veloso's two excellent phytosociological monographs $(1945,1946)$ show the difference between Ilhéus (lat. S. $14^{\circ} 48^{\prime}$, sea level) and Teresópolis (lat. S. $22^{\circ} 26^{\prime}$, 800 metres). The Lecythis-Sickingia association of Ilhéus has at least five tree species that compete for dominance: Lecythis ovata, Sickingia tinctoria, Peltogyne densiflora, Sorocea uriamen, Simaruba amara. There are, however, many others almost as frequent. Among the small trees (mesophanerophytes) Guarea suberosa, G. blancheti and Daphnopsis gemmiflora stand out. Shrubs are exceedingly numerous and include: Pilocarpus riedellianus, Psychotria rigida, Adenophelra megalophylla, Ouratea gigantophylla, Picramnia bahiensis.

The Teresópolis forest is somewhat simpler. The tree layer is dominated by five genera of Lauraceae: Nectandra, Ocotea, Urbanodendron, Acrodiclidion and Endlicheria; also important are Vochysia laurifolia, Tecoma spp. and Anona sp. The most remarkable small tree is the palm Euterpe edulis, and the most important shrub Psychotria estrellana.

An increase in altitude brings about more important changes, not only in composition, but also in structure. The selection and subsequent segrega. tion into local types operated by an increasingly cold climate upon the tree species seems analogous to that of the Eastern North American deciduous forest as described by BRAUN (1941). At about 1500 metres, a veritable dominance is sometimes achieved by Cabralea eichleriana or by species of Croton.

A montane rainforest at about 1800 metres in the Serra do Itatiaia (fig. 4) consisted mainly of Cabralea (about 15 metres high), with an understory of Croton, Leandra, Protium and a species of Rosaceae. Smaller shrubs were numerous and included species of Ocotea, Cestrum, Miconia, Prunus sphaerocarpa, Leandra laxa. Epiphytes showed an exceedingly dense growth and in. cluded enormous Bromeliaceae (v.g. Aechmaea distichantha) and Araceae, a large Hippeastrum, a host of tiny Orchidaceae, and hanging Cactaceae (Rhipsalis spp.). Herbaceous growth was also quite abundant, maybe owing to a certain amount of disturbance, and consisted mostly of Hydrocotyle sp., Asplenium harpeodes var. Glaziovii and Hesperozygis myrtoides. A few climbers were in evidence, but no lianas. Birds were extremely numerous and included a small dove (Columba plumbea plumbea), a tanager (Tangara desmaresti), a kingbird (Knipolegus lophotes) several humming-brids (Clytolaema rubricauda).

Somewhat above that level, between 1800 and 2000 metres, where the climate is cold enough to allow the formation of bogs, the forest, if not actually elfin, is much reduced in size and is dominated by Roupala lucens, Wein. 
mannia sp., Rapanea sp. and Clethra brasiliensis. These trees have been almost entirely destroyed by fire and replaced by a small bamboo (Chusquea pinifolia), shrubs of the Compositae family and grassy steppes and bogs.

Secondary forests of many types, however, are a more familiar sight than any of the above-described. Much of the escarpment that borders the eastern edge of the Coastal Range is covered with second-growth forest. Tibouchina estrellensis and Cassia multijuga var. grandiflora form a very homogenous association of rather small trees, above which remnants of the climax, such as Cedrela fissilis, Cariniana excelsa, Chorisia speciosa arise loftily. Several species of Cecropia (always a sign of disturbance) occupy different ecological positions, mostly in subclimax. Palms and bamboos are very quick to fill in gaps in the forest.

Another interesting species, because of its present rarity is "pau brasil" (Caesalpinia echinata) the tree that gave its name to the country. It seems likely that it also was a subclimax species, as it seems to have occurred in stands of some density.

The hydrosere also contains interesting types of forest. For instance, the mangrove, with its zonation of three different trees: Rhizophora mangle, Avicennia tomentosa and Laguncularia racemosa (DANSEREAU, 1947). These trees grow only in tidal mud and sand. But such a zone is sometimes of considerable extent, as in the vicinity of the great port of Santos (LuzDERWALDT, 1919). Freshwater swamp forests of the lowlands are dominated by Tabebuia ovalifolia, a small tree covered with epiphytes. This interesting association has been almost completely destroyed, the light wood of the tamanqueiro being much in demand for the making of sandals.

3. Araucarilandia

The Paraná pine country is by far the most productive forest area. Up. wards of 70 per cent of Brazilian wood exports (SouzA 1945) are Araucaria angustifolia. This is a tall tree. It can reach 50 metres in height and 2 metres in diameter (CECCATO, 1943). It produces no branches in the lower three-fourths but has numerous verticils crowded at the top, especially when it grows in forests. It does especially well in deep, not too acid soils, can withstand frost and even occasional snowfalls (see picture in Brazilian Department of External Affairs' 1945 book, p. 48).

The pine forest covers an extensive area and has been much exploited. It regenerates well in its native climate (Fig. 2, zone 3 ) but elsewhere has to be planted. These pine forests are nearly like those of the boreal hemisphere. The two lower strata of imbuia (Phoebe porosa) and herva maté (Ilex paraguariensis) increase in density when the pines are cut. In fact, in some areas this is done deliberately, the exploitation of the latter being more profitable.

There are relic colonies of pine forest in the States of Sāo Paulo, Rio de Janeiro and Minas Gerais, at altitudes of approximately 1500 metres. There, imbuia is replaced by Podocarpus lambertii and sellowi. (Fig. 5)

A somewhat disturbed pine forest at Campos do Jordāo (State of Sāo Paulo) at about 1600 metres, had Paraná pines 25-30 metres high, forming a rather open canopy (Fig. 5) with denser undergrowth (about 10 metres high) 
mostly of Podocarpus lambertii and a few Drimys winteri, Aspidosperma sp., Jacaranda sp. The shrubs were predominantly Melastomataceae, Myrtaceae, Rubiaceae and a few tree ferns. The herbaceous synusia was quite dense, Coccocypselum Hydrocotyle and ferns being well represented. Epiphytes were largely lichens, ferns, and mosses, a few Rhipsalis and a Tillandsia. On June 1st, 1946, frost covered the ground in all open spaces but did not enter the forest.

\section{ExplotTation OF Forests IN BRAzIL}

It is not too broad a statement to say that wood is not the principal product of Brazilian forests. In fact, nuts, oil, rubber, wax and fibre are certainly more important. Judging from the figures given by the Brazilian Department of External Affairs (1945) for the year 1942, the value of the latter was approximately $\$ 36,454,450.00$ as against about $\$ 11,929,650.00$ for wood exports (90 per cent Paraná pine). In the four southernmost states, there seems to have been 3740 sawmills with a total monthly capacity of 443,081 cubic metres. This does not mean that Brazil does not need and does not use wood. Brazilian industries use wood for fuel. Even some locomotives burn wood. It is also used for construction. But native forests are so difficult to manage that extensive artificial forests of Araucaria and of imported species are grown, mostly Eucalyptus saligna, E. rostrata, E. robusta. The cultivation of these Australian trees, successful though it is (ANDRADE, 1939), requires considerable work. None of them ever seed spontaneously.

The difficulty of managing tropical forests arises from the extremely large number of species involved and the extremely small number of any important commercial species per acre. SMITH and Phillips (1947) consider two trees to an acre a liberal estimate for mahogany (Swietenia mahogani). Difficulties of transport are another hazard. The latter tree, for instance, will float and can be carried long distances. SMITH and PHLLIPs liken annual tropical floods to "the northern blessing of snow with its sled transportation". But, on the whole, the methods used in temperate forests are inapplicable.

Also, Brazilian forests are very badly damaged and are in a very poor state of conservation because of irresponsible and unplanned lumbering and because of fires. There, ton, the myth of the inexhaustibility of natural resources has brought about waste, fire, erosion, floods, and so on.

The losses in soil fertility through deforestation are incalculable, inasmuch as the recuperation of fertility in the tropics is much slower and in many cases apparently hopeless (RAWITSCHER, 1946).

Today, forest legislation is very severe in the texts of the law. SouzA (1945) gives an excellent outline of the principal items. However, these rules are largely unapplied. Forest reserves and national parks are too few and mostly too small, and even there the law is not enforced.

In fact, the code itself, if it appears wise, is surely only approximately accurate, inasmuch as it must be based on work done elsewhere. There is no forestry school in the country. A few graduates of the School of Agronomy have studied forestry abroad but have subsequently been able to do very little 
research. In his general survey of forestry in Latin America, BevaN (1945) concluded that very much research was necessary as well as the training of native foresters. It is rather illusory to contemplate educating the general public in forest conservation when so little is actually known of soil and vegetation dynamism. The application of ecological methods to the study of tropical conditions is still in an early phase. Adequate adjustments of current methods and criteria remain to be found before such problems can be solved.

\section{BIBLIOGRAPHY}

Andrade, Edmundo Navarro de, 1939.

O Eucalipto. 124 pp. Ediçāo Chacaras e Quintais, Sāo Paulo.

Azevedo, A. de, 1945.

Geografia do Brasil. I. A. terra. O Homen. A Economia. 283 pp. Biblioteca Pedagogica Brasileira. Vol. 139. Companhia Editora Nacional. Sāo Paulo.

Azevedo, A. de, 1946.

Geografia do Brasil. II. As regiōes geograficas. 316 pp. Biblioteca Pedagogica Brasileira. Vol. 145. Companhia Editoria Nacional. Sāo Paulo. Beard, J. S., 1944.

Climax vegetation in tropical America. Ecol., 25 (2): 127-158.

Bevan, Arthur, 1945.

Forestry in Latin America and its future. In F. Verdoorn. Plants and Plant Science in Latin America, pp. 174-176. Chronica Botanica Co., Waltham, Mass., U.S.A.

Braun, E. Lucy, 1941.

The differentiation of the deciduous forest of the Eastern United States. Ohio Journ. Sci., 51: 235-241.

Brazilian Department of External Affairs, 1945.

Brésil. Ressources, possibilités. 302 pp. Ministère des Relations Extérieures, Rio de Janeiro. (In French).

Burtt-Davy, J., 1938.

The classification of tropical woody vegetation-types. Imp. For. Inst. Pap. 13: 1-85.

Ceccato, G. do Nascimento, 1943. O pinho brasileiro.

Brasil, Min. Agr., Serv. Inf. Agric. 850: 1-39.

Conselho Nacional De Geografia, 1945.

Mapa do Brasil. Scale 1: 5,750,000.

Dansereau, Pierre, 1947.

Zonation et succession sur la restinga de Rio de Janeiro. I. Halosère. Rev. Canad. Biol., 6 (3) : 448.477.

Dansereau, Pierre, 1948.

Notas sôbre a biogeografia de uma parte da Serra do Mar. Rev. Bras. Geogr. (in press).

Felippe, J. Carneiro, 1947.

Sinopse do censo demografico. Dados gerais. 47 pp. Instituto Brasileiro de Geografia e Estatistica, Rio de Janeiro. 
Frenguelli, Joaquin, 1940.

Rasgos principales de fitogeografia argentina. Publ. Didact. Divulg. Cient. Mus. Plat., 2: 1-119.

Huber, Jacques, 1900.

Sur les campos de l'Amazone inférieur et leur origine. Actes Congr. Intern. Bot. Paris, 1: 387-400.

Huber, Jacques, 1906.

La végétation de la vallée du Rio Purús (Amazone). Bull. Herb. Boiss., II. 6 (4) : 249-276.

Köppen, W., 1923.

Die Klimate der Erde. Walter De Gruyte $\&$ Co., Berlin.

Lindman, C. A. M., 1900. Vegetationen i Rio Grande do Sul. Stockholm.

Luederwaldt, H., 1919.

Os manguesaes de Santos. Rev. Museu Paulista, 11: 309-408.

Lutzelburg, P. von, 1922-23.

Estudo botanico do Nordeste. Inspectoria Federal de Obras contra as Seccas, Publ. 57. Ser. 1. A. 3 vols. Rio de Janeiro.

Martius, K. F. P., von, 1840-1906. Flora brasiliensis. 15 vols. Munchen and Leipzig.

Oliveira, A. I. de, and O. H. Leonardos, 1943.

Geologia do Brasil. XXVI +813 pp. Min. Agr., Rio de Janeiro.

Parodi, L., 1945.

Las regiones fitogeograficas argentinas y sus relaciones con la industria forestal.

In F. Verdoorn, Plants and Plant Science in Latin America, pp. $127-132$.

Pauwels, G., 1941.

Algumas notas sôbre a distribuiçāo do campo e da mata no sul do pais e a fixedez do limite que os separa. Rev. Brasil. Geogr., 3 (3): 155-158.

Potsch, W., 1945.

O Brasil e suas riquezas. Brasilogia. XXXIV + 406 pp. Imprensa Nacional, Rio de Janeiro.

Rawitscher, F. K., 1946.

Die Erschöpfung tropischer Böden infolge der Entwaldung. Acta Tropica, 3 (3) : 211-241.

Rawitscher, F. K., M. G. Ferri e M. Rachid, 1943.

Profundidade dos solos e vegetação em campos cerrados do Brasil meridional. Anais Acad. Brasil. Ciencias, 15 (4) : 267.

Rawitscher, F. K., e M. Rachid, 1946.

Troncos subterrâneos de plantas brasileiras. Anais Acad. Brasil. Ciencias, 18 (4): 261-280.

Sampaio, A. J., de, 1945.

Fitogeografia do Brasil. Biblioteca Pedagogica Brasileira. Coll. Brasiliana. Vol. 35, 372 pp. Companhia Editora Nacional. Sāo Paulo.

Schimper, A. F. W., 1898.

Pflanzengeographie auf physiologischer Grundlage. Jena. 
Shantz, H. L., and R. Zon, 1924.

Natural Vegetation. 29 pp. In Atlas of American Agriculture. United States Department of Agriculture, Washington, D.C.

Smith, J. Russell and M. Ogden Phillips, 1947. Industrial and commercial geography. $\mathrm{XV}+978$ pp. Henry Holt \& Co., New York.

Smith, Lyman B., 1945.

The vegetation of Brazil. In F. Verdoorn. Plants and Plant Science in Latin America. pp. 297-302. Chronica Botanica Co., Waltham, Mass.

Society of American Foresters, 1940. Forest cover types of the Eastern United States. 3rd edition. Washington, D.C.

Souza, Paulo F. de, 1945

The Brazilian Forests. In F. Verdoorn. Plants and Plant Science in Latin Almerica, pp. 111-119. Chronica Botanica Co., Waltham, Mass., U.S.A.

Veloso, H. P., 1945.

As comunidades e as estaçōes botanicas de Teresópolis, Estado do Rio de Janeiro. Bol. Mus. Nac. Bot. 3: 1-95.

Veloso, H. P., 1946.

A vegetaçāo no municipio de Ilhéus, Estado da Bahia. I. Estudo sine, cologico das áreas de pesquisas sôbre a febre amarela silvestre realizado pelo S.E.P.F.A. Mem. Inst. Oswaldo Cruz, 44 (1) : 13-103.

Warming, E., 1899.

On the vegetation of tropical America. Bot. Gaz., 27 (1): 1-18.

Warming, Eugene, 1909.

Oecology of Plants. XI +422 pp. Oxford University Press, London. 